\title{
Malignus májdaganatok miatt végzett laparoszkópos minor reszekciók eredményei az első 50 eset kapcsán
}

\author{
Sztipits Tamás dr. ${ }^{1}$ - Mészáros Péter dr. ${ }^{1}$ \\ Dubóczki Zsolt dr. ${ }^{1}$ - Oláh Gergely dr. ${ }^{1}$ - Mózer Andreas dr. ${ }^{1}$ \\ Strausz Tamás dr. $^{2}$. Mersich Tamás dr. ${ }^{1}$ \\ ${ }^{1}$ Országos Onkológiai Intézet, Daganatsebészeti Központ, Hasi Sebészeti Osztály, Budapest \\ ${ }^{2}$ Országos Onkológiai Intézet, Sebészi és Molekuláris Daganatpatológiai Centrum, Budapest
}

\begin{abstract}
Bevezetés: A laparoszkópos technika a máj malignus daganatainak sebészetében egyre szélesebb körben elfogadott. A minimálinvazív technika előnyei mellett több nemzetközi tanulmány alapján a laparoszkópia nem jelent onkológiai kompromisszumot.

Célkitüzés: Célunk az Intézetünkben végzett laparoszkópos és nyitott májreszekciók összehasonlítása a laparoszkópos tanulási fázis lezárultával.

Módszer: Az osztályunkon 2013. 01. 01. és 2017. 03. 31. között végzett minor májreszekciók adatait retrospektív módon vizsgáltuk. Minor reszekciónak a maximum 2 szegmentumot érintő mútétet tekintettük. Elemeztük az eltávolított szegmentumok számát, a mútéti időt, a 30 napos morbiditást és mortalitást, a posztoperatív transzfúzió szükségességét, a kórházi ápolás hosszát, az Rl-reszekciók arányát és reszekciósszél-távolságát.

Eredmények: 2013. 01. 01. és 2017. 03. 31. között 178 minor májreszekciót végeztünk malignus májdaganat miatt, ebből 123 nyitott és 55 laparoszkópos beavatkozás volt. A kísérő betegségek, az életkor és a nemek tekintetében a betegcsoportok homogének voltak. A nyitott mútéti csoportban szignifikánsan több volt a bisegmentectomiák aránya $(\mathrm{p}<0,0001)$. A mútéti időtartam $(\mathrm{p}=0,91)$ és a perioperatív transzfúzió $(\mathrm{p}=0,102)$ tekintetében nem találtunk szignifikáns eltérést a hagyományos és a laparoszkópos csoport között. A posztoperatív szövődmények aránya nem mutatott szignifikáns különbséget $(\mathrm{p}=0,50)$, a mortalitás is megegyezett $(\mathrm{p}=0,34)$. Az Rl-reszekciók és az átlagos reszekciós távolság tekintetében sem mutatkozott szignifikáns eltérés a két csoport tekintetében $(\mathrm{p}=0,447 ; \mathrm{p}=$ $0,263)$. A laparoszkópos csoport tagjai szignifikánsan kevesebb időt töltöttek kórházban $(\mathrm{p}=0,0001)$, mint a hagyományos technikával operált betegek.

Következtetés: Eredményeink alapján a laparoszkópos technika onkológiai-sebészeti kompromisszum nélkül, szignifikáns mértékben csökkentette az ápolási napok számát; a 30 napos morbiditás és mortalitás tekintetében nem találtunk különbséget. Alkalmazását vizsgálatunk alapján biztonságosnak tartjuk malignus májdaganatok esetében. Orv Hetil. 2019; 160(3): 104-111.
\end{abstract}

Kulcsszavak: laparoszkópia, májdaganatok, májreszekció

\section{Comparison of open and laparoscopic minor liver resections for malignant tumours - based on the experience of the first 50 cases}

Introduction: Laparoscopic resection of liver malignancies is gaining acceptance. Besides the advantages of minimallyinvasive techniques, publications so far show no oncologic compromise of laparoscopy.

Aim: Our aim was to compare the results of our first fifty laparoscopic minor liver resections with traditional open procedures.

Method: We investigated laparoscopic and open minor liver resections performed in our institute between 01.01 . 2013 and 31. 03. 2017. Data were analysed retrospectively. Resection of maximum two segments was considered a minor resection. We compared the number of resected segments, intraoperative blood loss, operative time, 30 day morbidity and mortality, hospital stay, $\mathrm{Rl}$ resection ratio and resection margin width.

Results: During the given period, 123 open and 55 laparoscopic minor liver resections of malignant liver tumours were performed. Open and laparoscopic groups were similar considering age, sex and health status. The ratio of bisegmentectomies was significantly higher in the open group $(\mathrm{p}<0.001)$. Operation time $(\mathrm{p}=0.91)$ and peri-operative 
transfusion ratio did not differ in the two groups $(\mathrm{p}=0.102) .30$ day morbidity and mortality were consistent $(\mathrm{p}=0.50 ; \mathrm{p}=0.34)$, but patients in the laparoscopic group spent shorter time in hospital $(\mathrm{p}=0.0001)$. The average width of resection margins and the ratio of $\mathrm{Rl}$ resections showed no difference between open and laparoscopic groups $(\mathrm{p}=0.447 ; \mathrm{p}=0.263)$.

Conclusion: Our investigation indicates that in malignant liver tumours, laparoscopic resection significantly shortens hospital stay without oncologic compromise, even though 30 day morbidity and mortality does not show difference. We conclude that laparoscopic minor resection of malignant liver tumours is safe and feasible.

Keywords: laparoscopy, liver neoplasms, hepatectomy

Sztipits T, Mészáros P, Dubóczki Zs, Oláh G, Mózer A, Strausz T, Mersich T. [Comparison of open and laparoscopic minor liver resections for malignant tumours - based on the experience of the first 50 cases]. Orv Hetil. 2019; 160(3): 104-111.

(Beérkezett: 2018. július 18.; elfogadva: 2018. augusztus 20.)

\section{Rövidítések}

ASA $=$ (American Society of Anaesthesiologists) Amerikai Aneszteziológiai Társaság; CRP $=$ C-reaktív protein; $\mathrm{INR}=$ (international normalized ratio) nemzetközi normalizált ráta; LLR = (laparoscopic liver resection) laparoszkópos májreszekció; OLR = (open liver resection) hagyományos nyitott májreszekció; RCT $=$ (randomized controlled trial) randomizált kontrollált vizsgálat

Az elmúlt két évtizedben a laparoszkópos technika az onkológiai sebészet számos területén elfogadottá vált. Nemzetközi randomizált tanulmányok bizonyították, hogy a colorectalis daganatok kezelésében a laparoszkópos technika a morbiditási és kórházi tartózkodási mutatók javulását eredményezte, miközben az onkológiai eredmények egyenértékúek a hagyományos, nyitott technikáéival $[1,2]$.

Hasonló randomizált vizsgálat a májdaganatok esetében körülbelül 10 évet késett. A májsebészet a laparoszkópos technika bevezetésével és alkalmazásával késlekedést mutatott, melynek hátterében a technikai nehézségek, a vérzés kockázata és a rossz onkológiai eredmények miatti aggodalom állhatott.

Mindezek ellenére a technika fokozatosan terjedt, és 2008-ban a louisville-i konszenzuskonferencia során a terület szakértối megállapodtak, hogy a minimálinvazív technika gyakorlott sebészek kezében biztonságos alternatíva a perifériás minor májreszekciók esetében. A konszenzus megállapította, hogy a bal lateralis sectionectomia elvégzésére a laparoszkópos technika javasolt eljárás. Kiemelték továbbá a megfelelő képzések fontosságát [3].

Ezt követte 2014-ben a második laparoszkópos májsebészeti konszenzuskonferencia Moriokában, ahol a szakértői grémium a laparoszkópos major anatómiai reszekcióknak a felkészült teamek általi elvégzését is biztonságosnak ítélte [4].

A laparoszkópos és robotasszisztált májsebészet rohamos fejlődése következtében 2017-ben Southamptonban megrendezésre került az első európai konszenzuskonferencia is, mely részletes ajánlásokat fogalmazott meg a minimálinvazív major és komplikált reszekciók bevezetéséről, valamint a megfelelő képzésről [5].

Bár folyamatosan növekszik a laparoszkópos májsebészettel kapcsolatos tudományos publikációk száma, nemzetközi viszonylatban továbbra is kevés az irodalmi adat a témában. A hazai irodalomban a laparoszkópos májsebészeti technika alapján saját anyagot bemutató közlemények száma csekély, és a tanulóperiódusról, illetve benignus gócok sebészetérôl szól [6]. Az Országos Onkológiai Intézetben 2013 óta végzünk malignus májdaganatok miatt minimálisan invazív reszekciót, $\mathrm{s}$ a tavalyi évben a módszert tekintve tanulóperiódusunk lezárult. $\mathrm{Az}$ országban tudomásunk szerint munkacsoportunk rendelkezik a legnagyobb tapasztalattal és betegszámmal a laparoszkópos májreszekciók terén.

Közleményünk célja beszámolni az Intézetünkben malignus májdaganat miatt végzett májsebészeti tevékenységről, különös tekintettel a laparoszkópos és nyitott minor reszekciók összehasonlítására a rövid távú onkosebészeti eredmények tekintetében.

\section{Módszer}

A vizsgálat során elemeztük az Országos Onkológiai Intézet Daganatsebészeti Centrumában 2013. 01. 01. és 2017. 03. 31. között végzett laparoszkópos (LLR) és nyitott (OLR) minor májreszekciókat.

A vizsgálatokat retrospektív módon végeztük. Minor reszekciónak a maximálisan két szegmentumot érintő anatómiai vagy nonanatómiai májreszekciókat tekintettük.

A vizsgálatba minden olyan beteget bevontunk, akit malignus gócos májelváltozás gyanújával mủtétre vittünk, és maximálisan két májszegmentumot érintett a mútét. A beválasztás műtéttechnikai alapon történt, nem tettünk különbséget elsődleges vagy áttéti daganatok között.

Az összehasonlítás $2: 1$ arányban történt (OLR : LLR $=2: 1$ ). Összehasonlítottuk a betegcsoportok nemek és életkor szerinti eloszlását, az ASA-besorolásukat, vala- 
mint a mütétek során érintett májszegmentumok számát.

A rövid távú eredmények közül összehasonlítottuk a 30 napos morbiditást és mortalitást, melyeket a ClavienDindo-féle sebészi szövődmény-besorolás I-től V-ig terjedő skálája alapján osztályoztunk. A szövődménybeosztásban az I-es beavatkozást nem igényel, a II-es gyógyszeres kezelést tesz szükségessé, a III-as eszközös vagy sebészi ellátást követel, a IV-es súlyos életveszélyes szövődmény, míg az V-ös a beteg halálát jelzi.

Vizsgáltuk a posztoperatív transzfúzió szükségességét, a mütéti vérvesztést, a mütétek időtartamát és a kórházi tartózkodás átlagos hosszát a LLR- és az OLR-csoportban.

Összehasonlítottuk a mütét utáni 1 . és 4. napon regisztrált laborparaméterek közül a leukocytaszámot, a CRP-t, az INR-t és a transzaminázok szintjét a LLR- és az OLR-csoport esetében.

A szövettanilag malignusnak bizonyult gócok esetében elemeztük az R0- és az Rl-reszekciók arányát, valamint az R0-reszekciók esetében az átlagos reszekciós távolságot is összehasonlítottuk az OLR- és a LLR-csoportnál.

A normáleloszlást mutató parametrikus változók esetén t-tesztet, egyebekben a Mann-Whitney-féle U-próbát végeztük. Khi-négyzet-tesztet alkalmaztunk a kategorikus változók elemzéséhez. A kiértékelés során a p $<0,05$ szignifikanciaszintet fogadtuk el szignifikánsnak.

\section{Eredmények}

Az Országos Onkológiai Intézet Daganatsebészeti Centrumában 2013. 01. 01. és 2017. 03. 31. között 178 minor májreszekciót végeztünk malignus gócos májelváltozás miatt, ebból 123 nyitott (OLR) és 55 laparoszkópos (LLR) beavatkozás volt.

A laparoszkópos és a nyitott csoport között sem az átlagéletkor tekintetében (LLR: 63 [54-73]; OLR: 65
1. táblázat | Demográfiai adatok és tumorkarakter

\begin{tabular}{|c|c|c|c|c|}
\hline & & $\mathrm{p}$ & LLR & OLR \\
\hline $\mathrm{N}$ & & & 55 & 123 \\
\hline Életkor & & 0,3608 & $63(54-73)$ & $65(59-71)$ \\
\hline \multirow[t]{2}{*}{$\mathrm{Nem}$} & Férfi & 0,8711 & $28(50,9 \%)$ & $61(49,6 \%)$ \\
\hline & Nó & & $27(49,1 \%)$ & $62(50,4 \%)$ \\
\hline \multirow[t]{2}{*}{ Tumorkarakter } & Benignus & & $14(25,5 \%)$ & $11(8,9 \%)$ \\
\hline & Malignus & & $4 \mathrm{l}(74,5 \%)$ & $112(91,1 \%)$ \\
\hline
\end{tabular}

LLR = laparoszkópos májreszekció; $\mathrm{N}$ = a betegek száma; OLR = nyitott májreszekció; $\mathrm{p}$ = szignifikanciaszint

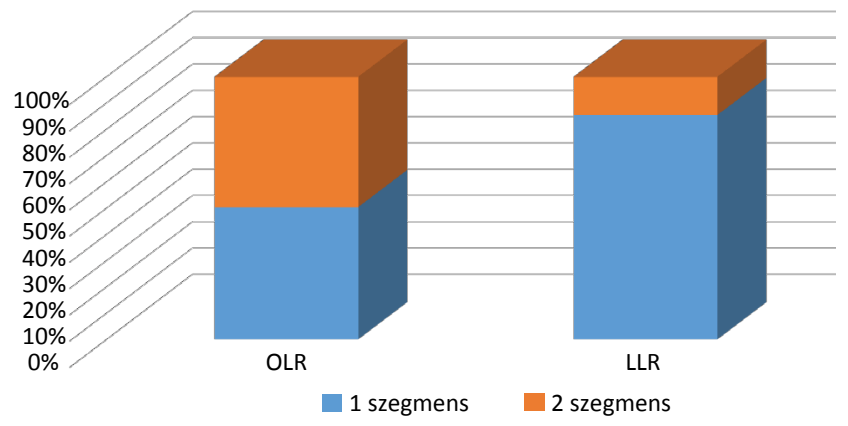

\begin{tabular}{l|l} 
1. ábra & $\begin{array}{l}\text { Az egy és két szegmentumot érintő májreszekciók aránya lapa- } \\
\text { roszkópos }(\text { LLR }) \text { és nyitott }(\mathrm{OLR}) \text { májmútéteknél }(\mathrm{p}<0,0001) \\
\text { LLR }=\text { laparoszkópos májreszekció; OLR = nyitott májreszekció }\end{array}$
\end{tabular}

[59-71]; $\mathrm{p}=0,3608)$, sem pedig a nemek szerinti megoszlásban (LLR: nő 27 [49,1\%], férfi 28 [50,9\%]; OLR: nő: 62 [50,4\%], férfi: 61 [49,6\%]) nem volt szignifikáns különbség.

A végleges szövettani vizsgálat a laparoszkópos csoportban $14(25,5 \%)$, míg a nyitott csoportban $11(8,9 \%)$ esetben nem igazolt malignitást (1. táblázat).

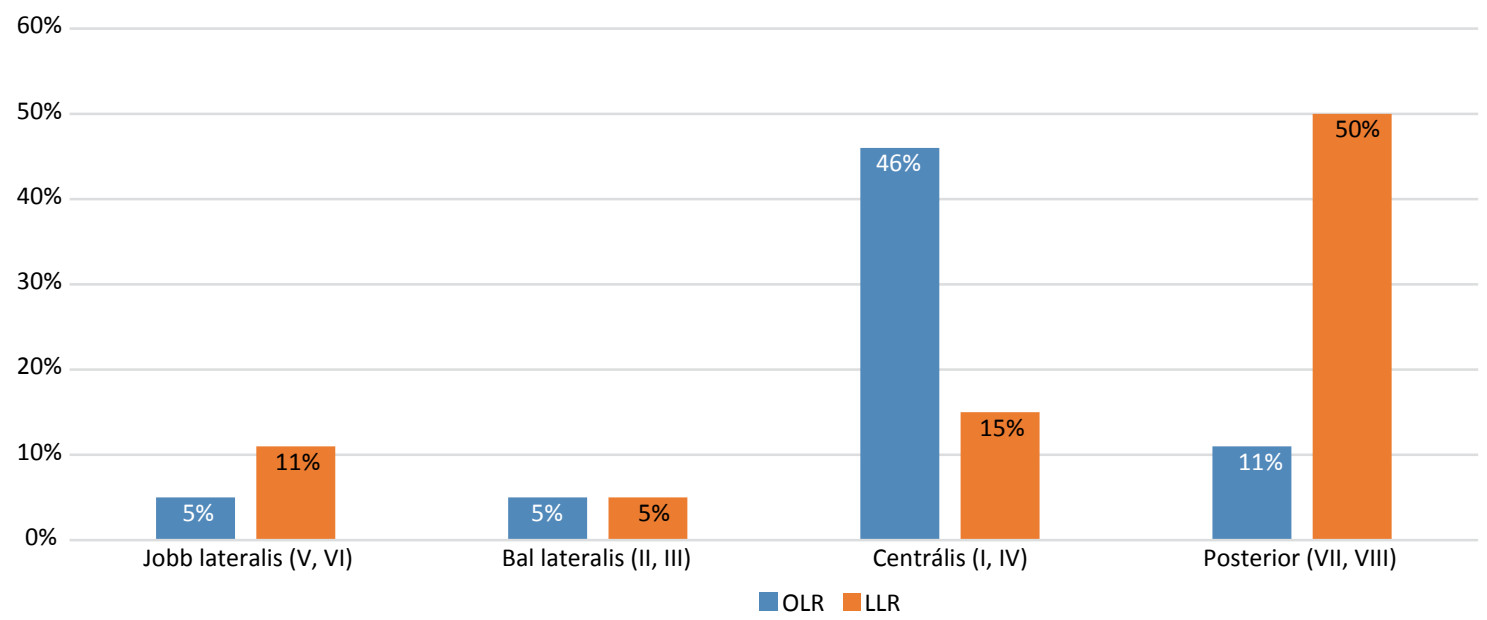

\begin{tabular}{l|l} 
2. ábra & Az Rl-reszekciók aránya a tumor elhelyezkedése szerint, laparoszkópos és nyitott reszekcióknál \\
$\mathrm{LLR}=$ laparoszkópos májreszekció; OLR = nyitott májreszekció
\end{tabular} 
2. táblázat

Laparoszkópos és nyitott májreszekciók posztoperatív eredményei

\begin{tabular}{|c|c|c|c|c|}
\hline & & $\mathrm{p}$ & LLR & OLR \\
\hline $\begin{array}{l}\text { Mütéti idő } \\
\text { (perc) }\end{array}$ & & 0,9095 & $\begin{array}{l}92,5 \\
(70-116,3)\end{array}$ & $90(70-120)$ \\
\hline Transzfúzió & & 0,1024 & $3(5,5 \%)$ & $17(13,8 \%)$ \\
\hline Szövődmények & $\begin{array}{l}\text { Clavien- } \\
\text { Dindo I-IV. }\end{array}$ & 0,4995 & $8(14,5 \%)$ & $23(18,7 \%)$ \\
\hline $\begin{array}{l}\text { Mortalitás ( } 30 \\
\text { napos) }\end{array}$ & $\begin{array}{l}\text { Clavien- } \\
\text { Dindo V. }\end{array}$ & 0,3416 & $0(0,0 \%)$ & $2(1,6 \%)$ \\
\hline $\begin{array}{l}\text { Ápolási idő } \\
\text { (napok) }\end{array}$ & & $<0,0001$ & $4(2-5)$ & $6(5-7)$ \\
\hline
\end{tabular}

LLR = laparoszkópos májreszekció; OLR = nyitott májreszekció; p = szignifikanciaszint

A két csoport adatait összevetve szignifikáns különbség mutatkozik az eltávolított szegmensek számát illetően. A LLR-csoportban 47 mono- $(85,5 \%)$ és 8 bisegmentectomiát $(15,5 \%)$, míg az OLR-csoportban 62 mono- $(50,4 \%)$ és 61 bisegmentectomiát végeztünk $(49,6 \%)(\mathrm{p}<0,0001)$. Mútét során mindkét csoportban a LigaSure ${ }^{\mathrm{TM}}$ eszközt (Medtronic, Minneapolis, MN, Amerikai Egyesült Államok) alkalmaztunk a leggyakrabban a parenchyma szétválasztására (1. ábra).

A műtéti idő tekintetében nem találtunk szignifikáns különbséget a laparoszkópos és a nyitott csoport között. A LLR-csoportban az átlagos mútéti idő 92,5 perc (70116,3) volt, míg az OLR esetében ez átlagosan 90 perc $(70,0-120,0)$ volt $(\mathrm{p}=0,9095)$.

A transzfúziós arányban sem találtunk szignifikáns különbséget a két csoport között $(\mathrm{p}=0,1024)$. A laparoszkópos beavatkozás során három esetben volt szükség vérátömlesztésre $(5,5 \%)$, míg a nyitott csoportban a vérátömlesztésben részesültek száma $17(13,8 \%)$ volt.
3. táblázat | Laparoszkópos és nyitott májreszekciók onkológiai-sebészeti eredményei

\begin{tabular}{llllc}
\hline & & $\mathrm{p}$ & LLR & OLR \\
\hline Reszekciós szél & $\mathrm{R} 0$ & 0,4471 & $32(78,0 \%)$ & $83(74,1 \%)$ \\
& $\mathrm{R} 1$ & & $7(17,1 \%)$ & $26(23,2 \%)$ \\
& $\mathrm{Rx}$ & & $2(4,9 \%)$ & $3(2,7 \%)$ \\
\cline { 2 - 5 } & Össz & & $41(100 \%)$ & $112(100 \%)$ \\
\hline $\begin{array}{l}\text { Reszekciós távolság } \\
(\mathrm{mm})\end{array}$ & & 0,2631 & $2(0,5-7)$ & $3(1-9)$ \\
\hline
\end{tabular}

LLR = laparoszkópos májreszekció; OLR = nyitott májreszekció; $\mathrm{p}=$ szignifikanciaszint

A posztoperatív szövődmények tekintetében nem találtunk szignifikáns eltérést a LLR- és az OLR-csoport között. A 30 napos morbiditás (Clavien-Dindo I-IVb) aránya a LLR-csoportban 14,5\%, míg az OLR-csoportban $18,7 \%$ volt $(\mathrm{p}=0,50)$.

A 30 napos mortalitás tekintetében sem találtunk szignifikáns eltérést. A nyitott csoportban két haláleset történt 30 napon belül $(1,6 \%)$, míg a laparoszkópos csoportban nem volt mortalitás $(\mathrm{p}=0,34)$.

$\mathrm{Az}$ ápolási napok száma a LLR-csoport esetében szignifikánsan kevesebb volt, mint az OLR-csoport esetében. Míg a LLR-csoportban az átlagos ápolási idő 4 nap volt (2-5), az OLR-csoport betegei átlagosan 6 napot (5-7) töltöttek kórházban $(\mathrm{p}<0,0001)$ (2. táblázat).

A malignus gócok esetében az érintett reszekciós szélek arányát és az átlagos reszekciós távolságot is vizsgáltuk.

A LLR-csoportban 7 esetben $(17,1 \%)$ volt érintett fokálisan a reszekciós szél, két esetben $(4,9 \%)$ pedig a reszekció nem volt megítélhető termikus károsodás miatt. Az OLR-csoportban 26 esetben volt érintett a reszekciós sík $(23,2 \%)$, míg 3 esetben $(2,7 \%)$ az R0-reszekció nem
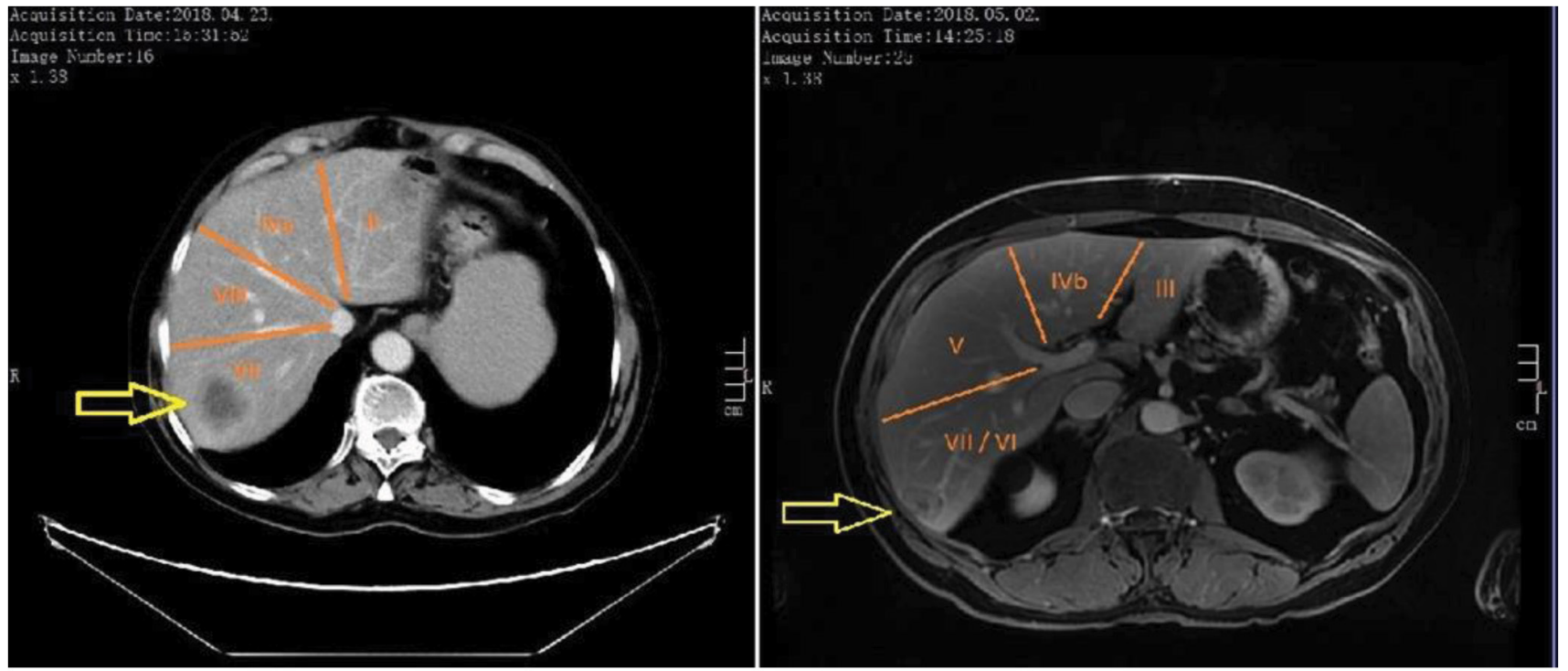
volt megítélhető szintén hőkárosodás következtében. Az Rl-reszekciók arányát tekintve az OLR- és a LLR-csoport között nem találtunk statisztikailag szignifikáns különbséget $(\mathrm{p}=0,447)$.

Az átlagos reszekciós távolság a LLR esetében $2 \mathrm{~mm}$ (0,5-7), míg az OLR esetében $3 \mathrm{~mm}$ (1-9) volt ( $\mathrm{p}=$ 0,2631) (3. táblázat).

$\mathrm{Az} \mathrm{Rl-reszekciókat} \mathrm{részletesebben} \mathrm{is} \mathrm{megvizsgáltuk}$ aszerint, hogy a máj melyik területén történt a reszekció. Jobb (V, VI) és bal (II, III) lateralis, centrális (I, IV) és posterior (VII, VIII) felosztás szerint csoportosítottuk a pozitív széllel végződő reszekciókat.

A nyitott csoportban a centrális szegmentumokon végzett mútétek esetén volt a legmagasabb az Rl-reszekciók aránya (46\%), míg a lateralis és hátsó szegmentumokban ez az arány jóval alacsonyabb volt (5-11\%).

A laparoszkópos csoportban az Rl-reszekciók döntő többségét a posterior szegmentumokon végzett mútétek során észleltük, itt az érintett szélek aránya 50\% volt, míg a lateralis szegmentumokban 5-11\%, a centrális területen $15 \%$ volt ez az arány (2. ábra).

\section{Megbeszélés}

A laparoszkópia fejlődésével a májdaganatok sebészetében is egyre szélesebb körben elfogadott a minimálinvazív technika alkalmazása. Míg kezdetben a perifériás és benignus elváltozások esetében tartották elfogadottnak, a louisville-i, majd a moriokai és a legutóbbi southamptoni konszenzus óta a laparoszkópos májsebészet a malignus tumorok kezelésében is polgárjogot nyert $[3-5,7]$.

Mindezek ellenére még nem állnak rendelkezésünkre nagyszámú prospektív randomizált kontrollált tanulmányok eredményei. Az első prospektív multicentrikus RCT, az Orange II 2010 és 2014 között zajlott 10 európai intézményben, és a hagyományos és a laparoszkópos bal lateralis sectionectomia eredményeit vizsgálta. Sajnos a kevés és lassú beválasztás miatt a vizsgálat sikertelenül zárult, de az előzetes eredmények a vizsgált paraméterek tekintetében (teljes funkcionális felépülés, morbiditás, ápolási napok száma) nem talált eltérést a laparoszkópos és a nyitott mütéti csoport között [8].

Tavaly közölték az első sikeres prospektív RCT, a norvég Oslo CoMet Trial eredményeit, melyek a 30 napos morbiditás tekintetében szignifikáns különbséget találtak a laparoszkópia javára. Ez a vizsgálat 273 beteget választott be [9].

Retrospektív vizsgálatunk a nemzetközi irodalom tükrében is jelentékeny számú beteg adatának elemzését tette lehetővé. Összehasonlításképpen, egy 7 centrumot érintő kínai metaanalízis 627 beteg adatait vizsgálta (241 laparoszkópos és 383 nyitott) [10], míg az eddigi legnagyobb nemzetközi irodalmat áttekintő amerikai tanulmány 127 eredeti közleményben szereplő 2804 beteg adatait elemezte [11].

A tanulmányunk során vizsgált végpontok nagy része (30 napos morbiditás és mortalitás, a transzfúzió aránya,

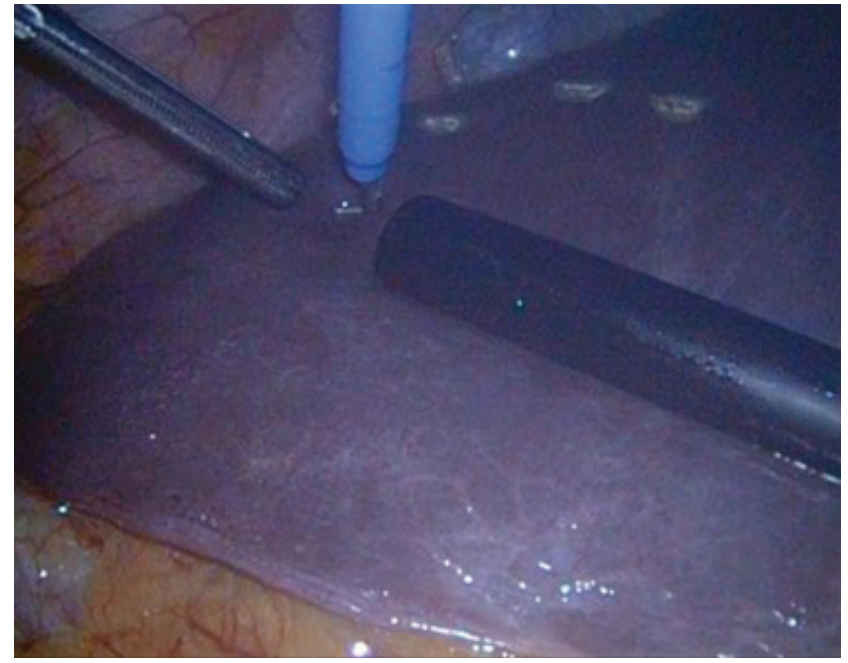

4. ábra Intraparenchymalis májáttét reszekciós síkjának kijelölése laparoszkópos ultrahanggal

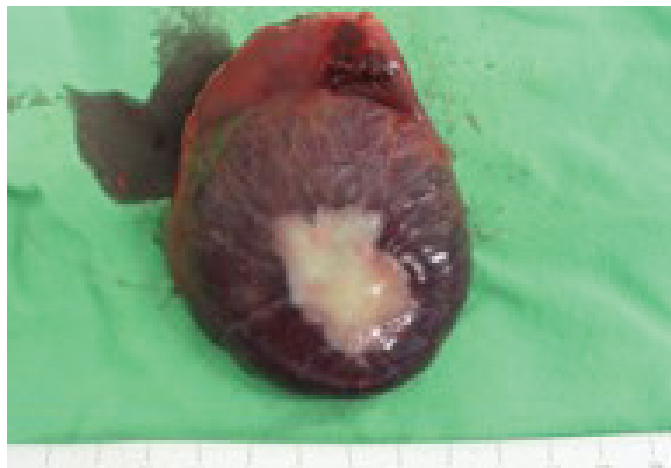

5. ábra Felszínképző perifériás májáttét laparoszkópos reszekciót követően

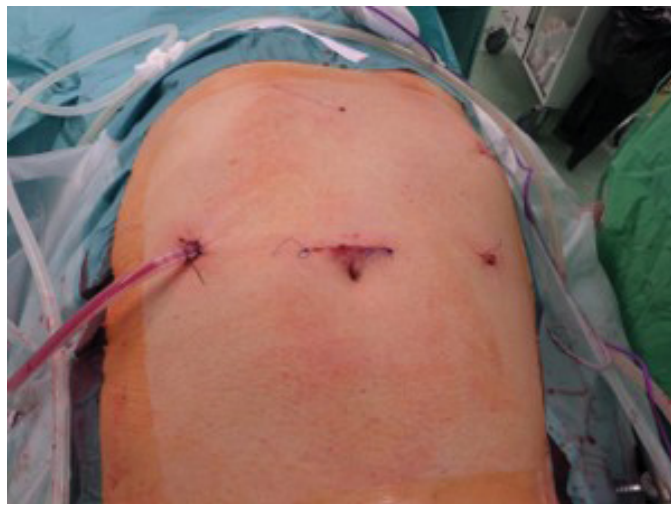

6. ábra

| Műtéti sebek laparoszkópos minor májreszekciót követően

az ápolás hossza, az R0-reszekciók aránya, a mútéti idő) a legtöbb közleményben fellelhető. Egyes nemzetközi tanulmányok foglalkoznak a laparoszkópos és a nyitott mútétek hosszú távú financiális összevetésével, mi ezt a területet jelenleg nem érintettük [9].

Összehasonlításunkban kizárólag minor reszekciók eredményeit vizsgáltuk, mely definíció szerint legfeljebb 
két májszegmentumot érinthetett. A vizsgált populáció homogénnek bizonyult.

$\mathrm{Az}$ adatok elemzése során egyértelmúvé vált, hogy a laparoszkópos csoportban (LLR) sokkal nagyobb arányban vannak az egy szegmenset érintő mütétek $(85,5$ versus $15,5 \%$ ), míg a nyitott csoportban (OLR) a mono- és bisegmentectomiák aránya nagyjából megegyezett $(50,4$ versus 49,6\%). Ennek magyarázata vélhetően az, hogy tanulási görbénk elején a kevésbé komplikált elhelyezkedésű szoliter tumorokat vállaltuk laparoszkópos úton megközelíteni (4-6. ábra).

Feltehetően részben ez is a magyarázata annak, hogy a mütéti idő tekintetében nem észleltünk szignifikáns eltérést a LLR- és az OLR-csoport között (LLR 92,5 perc [70-116,3]; OLR 90 perc [70,0-120,0]; p = 0,9095). Ez az eredmény korrelál a nemzetközi irodalom minor reszekciókat elemző közleményeivel, bár az átlagos mútéti idő a mi esetünkben mindkét csoportban rövidebb [12].

A transzfúziós arány tekintetében nem találtunk szignifikáns különbséget a LLR- és az OLR-csoport között $(5,5 \%$ versus $13,8 \%)$, annak ellenére sem, hogy az OLRcsoportban sokkal nagyobb arányban voltak két szegmentumot érintő mütétek. Ezt azzal magyarázzuk, hogy a májállomány szétválasztásának technikája minden mütéttípusnál megegyezett, így nem járt nagyobb vérzéssel a nagyobb reszekció. Továbbá a mütéti idő is hasonlóan alakult, így az elhúzódó mútétből adódó esetleges további vérvesztés elkerülhető volt. A transzfúziók aránya megegyezik az irodalmi adatokkal [9].

Vizsgálatunk egyik központi eleme - más nemzetközi vizsgálatokkal megegyezően - a 30 napos morbiditás és mortalitás összehasonlítása volt. A posztoperatív szövődmények Clavien-Dindo-skála alapján történő összehasonlítása azt igazolta, hogy a Clavien-Dindo I-IV-es komplikációk tekintetében nincs szignifikáns különbség a LLR- és az OLR-csoport között (14,5\% versus $18,7 \%$; $\mathrm{p}=0,50)$.

Hasonlóképpen, a 30 napos mortalitás tekintetében sem észleltünk szignifikáns eltérést a két csoport között (OLR: 1,6\% versus LLR 0\%). A nyitott csoportban előfordult 2 haláleset közül az egyik esetben szimultán bélreszekció is történt, a bélvarrat-elégtelenség és a következményes hashártyagyulladás okozta a beteg halálát, míg a másik esetben rekesz alatti tályog és szeptikus sokk volt a halált kiváltó tényező. A laparoszkópos csoportban nem volt 30 napon belüli haláleset.

$\mathrm{Az}$ áttekintett irodalomban egyes szerzók a laparoszkópos csoportban általában kevesebb szövődményről számolnak be [9, 10], míg más közlemények nem találnak eltérést a 30 napos morbiditás tekintetében [13].

Saját eredményeink alapján a nyitott és a laparoszkópos módszer korai morbiditási mutatóiban nem találtunk eltérést. Ennek oka talán az lehet, hogy a 30 napon belül jelentkező komplikációk egy jelentős része - mint az epecsorgás, a tályogképződés vagy a hasüregi vérzés - a májreszekcióval és nem a feltárás módjával van összefüg- gésben. Szövődményeink aránya nem különbözik az áttekintett nemzetközi irodalomban közöltektől $[8,9$, 11]. A kórházban töltött átlagos idő mégis indirekt módon jelzi a minimálinvazív megközelítés jótékony hatását. Vizsgálatunkban a LLR-csoport esetében az ápolási idő hossza szignifikánsan rövidebb volt az OLR-csoporthoz képest (4 nap [2-5] versus 6 nap $(5-7) \mathrm{p}<0,0001$ ). Ennek magyarázata - megegyező morbiditási mutatók mellett - a kisebb posztoperatív fájdalomban és a gyorsabb mobilizálhatóságban keresendő.

A malignus gócok esetében az érintett reszekciós szélek arányát és az átlagos reszekciós távolságot is vizsgáltuk. Rl-reszekciónak tekintettük, ha a reszekciós sík a tumortól kevesebb, mint 1 mm-re haladt, azt elérte, vagy ha szakadozottság miatt nem volt megítélhető.

A LLR-csoportban 7 esetben $(17,1 \%)$, míg az OLRcsoportban 26 esetben volt érintett a reszekciós sík $(23,2 \%)$, az Rl-reszekciók arányát tekintve az OLR- és a LLR-csoport között nem találtunk statisztikailag szignifikáns különbséget $(\mathrm{p}=0,447)$.

Az átlagos reszekciós távolság a LLR esetében $2 \mathrm{~mm}$ (0,5-7), míg az OLR esetében $3 \mathrm{~mm}$ (1-9) volt ( $\mathrm{p}=$ $0,2631)$.

A nemzetközi irodalomban a legtöbb közlemény az 1 $\mathrm{mm}$ alatti reszekciós síkot $\mathrm{Rl}$-reszekciónak tekinti, azonban nem minden közlemény definiálja az Rl-reszekció kritériumát $[9,14,15]$. Szintén egyes közlemények külön kategóriába sorolják az $1 \mathrm{~mm}$ alatti, de tumormentes, valamint a tumorosan érintett reszekciós széleket, ami a százalékos arányok összehasonlítását tovább nehezíti [9].

A szükséges reszekciós távolság kérdése az utóbbi évtizedekben többször napirendre került. Ekberg és munkacsoportja 1986-ban colorectalis áttétek esetében a 10 mm-es reszekciós síkot tartotta indokoltnak, melyet Cady és mtsai 1998-ban megerősítettek [16, 17]. Ezt követően Kokudo és mtsai egy 2002-es tanulmányukban már a 2 mm-es ép szegélyt tartották onkológiailag elfogadhatónak [18].

Pawlik és mtsai 2005-ben 557 betegen végzett retrospektív multicentrikus vizsgálata a reszekciós szél és a daganatkiújulás közötti összefüggések vizsgálata során kimutatta, hogy nincs túlélési előnye az $1 \mathrm{~mm}$ feletti reszekciós távolságnak, a vizsgálat során csak a mikroszkóposan érintett reszekciós szél esetén volt szignifikánsan rosszabb a hosszú távú túlélés [19].

Vizsgálatunkban az $1 \mathrm{~mm}$ alatti vagy nem megítélhető reszekciós síkot $\mathrm{Rl}$-nek vettük. Ebbe a kategóriába lényegében kizárólag olyan szövettani minták kerültek, amelyekben a reszekciós sík mikroszkóposan érintett volt, egy-két májsejtnyi vagy kötőszövetrostnyi ép szél volt látható, vagy a termikus károsodás miatt az ép szélről nyilatkozni nem lehetett.

Az Rl-reszekciók aránya nagyságrendileg megfelel a nemzetközi irodalomban közölt adatoknak [9, 14, 15], azonban a különböző közleményekben feltüntetett ada- 
tok pontos összehasonlítását az Rl-reszekció hiányos vagy eltéró értelmezése korlátozhatja.

Az Rl-reszekciókat külön megvizsgáltuk annak alapján, hogy a máj mely területét érintette a mútét. Jobb (V, VI) és bal (II, III) lateralis, centrális (I, IV) és posterior (VII, VIII) felosztás szerint csoportosítottuk a pozitív széllel végződő reszekciókat.

A nyitott csoportban a centrális szegmentumok mútéte esetén volt a legmagasabb az Rl-reszekciók aránya (46\%), míg a lateralis és hátsó szegmentumokban ez az arány jóval alacsonyabb volt (5-11\%).

A centrális májszegmentumokon végzett parenchymakímélő mütét a portalis és a vena hepatica képletek közelsége miatt sokszor nagy kihívást jelent, mivel ezek a struktúrák korlátozzák a reszekciós síkok kiterjesztését, így ezekben az esetekben a minor reszekció magasabb $\mathrm{Rl-aránnyal} \mathrm{végződhet.} \mathrm{Ez} \mathrm{magyarázhatja} \mathrm{az} \mathrm{általunk} \mathrm{is}$ észlelt magasabb Rl-arányt, továbbá felveti a kérdést, hogy nem lenne-e érdemes anatómiai major reszekciót végezni ezekben az esetekben.

A laparoszkópos csoportban az Rl-reszekciók döntô többségét a posterior szegmentumok mütétei során észleltük, itt az érintett szélek aránya 50\% volt, míg a lateralis szegmentumokban $5-11 \%$, a centrális területen $15 \%$ volt ez az arány (2. ábra).

Bár bal oldalfekvésben, a jobb májlebeny teljes mobilizálásával a hátsó szegmentumok laparoszkópos úton is hozzáférhetők, a mély reszekciós szél az eszközök májgörbületre történő „felfekvése” miatt gyakran igen nehezen biztosítható (3. ábra). A laparoszkópos módszer a felszínközeli elváltozások esetében kellő biztonságot adhat, azonban a mélyebben elhelyezkedő gócok a hátsó szegmentumokban komoly kihívást jelenthetnek [2022]. A hátsó szegmentumok laparoszkópos megközelítésével magyar közlemény is foglalkozik, Dede és mtsai a régió laparoszkópos megközelítését választott esetben biztonságosnak ítélik [23].

\section{Következtetés}

A laparoszkópia a májsebészetben is egyre szélesebb körben elfogadott, a minor májreszekciókban a nemzetközi konszenzuskonferenciák óta kifejezetten ajánlott eljárás.

A kezdetekben szakértői véleményeken, konszenzuson és retrospektív analíziseken alapuló térhódítását tovább segítheti az elsô sikeres prospektív randomizált tanulmány, mely egyértelmü előnyöket fogalmazott meg a laparoszkópia javára a perioperatív morbiditás tekintetében, miközben nem csorbult az onkológiai radikalitás.

Mindezek ellenére továbbra is kevés és kis esetszámú irodalmi adat áll rendelkezésünkre, többségük retrospektív vizsgálat formájában, és kevés a hosszú távú túlélést vizsgáló közlemény. Magunk a laparoszkópos májsebészet tanulóperiódusát sikeresen lezártuk, figyelmünket a közeljövőben a hátsó szegmentumok biztonságosabb feltárására, a major reszekciók bevezetésére és a késői onkológiai kimenetel monitorozására tervezzük fordítani. A minor reszekciók esetében kellő körültekintéssel és megfelelő tréninggel a malignus májdaganatok minimálisan invazív reszekciója elvégezhető olyan centrumokban, ahol a team mind a nyitott májsebészetben, mind a laparoszkópos onkológiai sebészetben járatos.

Anyagi támogatás: A szerzők anyagi támogatásban nem részesültek.

Szerzői munkamegosztás: Sz. T.: A közlemény megírása, szerkesztése. M. P., M. T., D. Zs., O. G., Sz. T.: A mütétek végzése. M. A.: Statisztikai elemzések. S. T.: A szövettani minták konzultálása. A cikk végleges változatát valamennyi szerző elolvasta és jóváhagyta.

Érdekeltségek: A szerzőknek nincsenek érdekeltségeik.

\section{Irodalom}

[1] COLOR Study Group. COLOR: a randomized clinical trial comparing laparoscopic and open resection for colon cancer. Dig Surg. 2000; 17: 617-622.

[2] van der Pas MH, Haglind E, Cuesta MA, et al., for the COlorectal cancer Laparoscopic or Open Resection II (COLOR II) Study Group. Laparoscopic versus open surgery for rectal cancer (COLOR II): short-term outcomes of a randomised, phase 3 trial. Lancet Oncol. 2013; 14: 210-218.

[3] Buell JF, Cherqui D, Geller DA, et al., World Consensus Conference on Laparoscopic Surgery. The international position on laparoscopic liver surgery: the Louisville Statement, 2008. Ann Surg. 2009; 250: 825-830.

[4] Wakabayashi G, Cherqui D, Geller DA, et al. Recommendations for laparoscopic liver resection: a report from the second international consensus conference held in Morioka. Ann Surg. 2015; 261: 619-629.

[5] Abu Hilal M, Aldrighetti L, Dagher I, et al. The Southampton Consensus Guidelines for Laparoscopic Liver Surgery: from indication to implementation. Ann Surg. 2018; 268: 11-18.

[6] Kupcsulik P, Hahn O, Szíjártó A, et al. Laparoscopic surgery of benign liver tumours. [Benignus májdaganatok laparoszkópos resectiója.] Magy Seb. 2015; 68: 3-7. [Hungarian]

[7] Jakab F. Milestones in liver surgery. [Mérföldkövek a máj sebészetében.] Orv Hetil. 2018; 159: 375-383. [Hungarian]

[8] Wong-Lun-Hing EM, van Dam RM, van Breukelen GJ, et al. Randomized clinical trial of open versus laparoscopic left lateral hepatic sectionectomy within an enhanced recovery after surgery programme (ORANGE II study). BJS 2017; 104: 525-535.

[9] Fretland ÅA, Dagenborg VJ, Bjørnelv GM, et al. Laparoscopic versus open resection for colorectal liver metastases. The OSLOCOMET randomized controlled trial. Ann Surg. 2018; 267: 199-207.

[10] Luo LX, Yu ZY, Bai YN. Laparoscopic hepatectomy for liver metastases from colorectal cancer: a meta-analysis. J Laparoendosc Adv Surg Tech A 2014; 24: 213-222.

[11] Nguyen KT, Gamblin TC, Geller DA. World review of laparoscopic liver resection $-2,804$ patients. Ann Surg. 2009; 250: 831-841.

[12] Johnson LB, Graham JA, Weiner DA, et al. How does laparoscopic-assisted hepatic resection compare with the conventional open surgical approach? J Am Coll Surg. 2012; 214: 717-723.

[13] Inoue $Y$, Hayashi $M$, Tanaka $R$, et al. Short-term results of laparoscopic versus open liver resection for liver metastasis from colorectal cancer: a comparative study. Am Surg. 2013; 79: 495-501. 
[14] Lewin JW, O'Rourke NA, Chiow AK, et al. Long-term survival in laparoscopic vs open resection for colorectal liver metastases: inverse probability of treatment weighting using propensity scores. HPB (Oxford) 2016; 18: 183-191.

[15] Aghayan DL, Pelanis E, Avdem Fretland Å, et al. Laparoscopic parenchyma-sparing liver resection for colorectal metastases. Radiol Oncol. 2017; 52: 36-41.

[16] Ekberg H, Tranberg KG, Andersson R, et al. Determinants of survival in liver resection for colorectal secondaries. Br J Surg. 1986; 73: 727-731

[17] Cady B, Jenkins RL, Steele GD Jr, et al. Surgical margin in hepatic resection for colorectal metastasis: a critical and improvable determinant of outcome. Ann Surg. 1998; 227: 566-571.

[18] Kokudo N, Miki Y, Sugai S, et al. Genetic and histological assessment of surgical margins in resected liver metastases from colorectal carcinoma: minimum surgical margins for successful resection. Arch Surg. 2002; 137: 833-840.

[19] Pawlik TM, Scoggins CR, Zorzi D, et al. Effect of surgical margin status on survival and site of recurrence after hepatic resection for colorectal metastases. Ann Surg. 2005; 241: 715-722.
[20] Cho JY, Han HS, Yoon YS, et al. Experiences of laparoscopic liver resection including lesions in the posterosuperior segments of the liver. Surg Endosc. 2008; 22: 2344-2349.

[21] Morise Z. Laparoscopic liver resection for posterosuperior tumors using caudal approach and postural changes: a new technical approach. World J Gastroenterol. 2016; 22: 10267-10274.

[22] Guro H, Cho JY, Han HS, et al. Laparoscopic liver resection of hepatocellular carcinoma located in segments 7 or 8. Surg Endosc. 2018; 32: 872-878.

[23] Dede K, Papp G, Salamon F, et al. Laparoscopic resection of a liver metastasis from segment VII. Case report. [A máj VII-es szegmentumában igazolt áttéti daganat laparoszkópos reszekciója.] Orv Hetil. 2016; 157: 796-800. [Hungarian]

(Sztipits Tamás dr., Budapest, Ráth Gy. u. 7-9., 1122 e-mail: sztipits.tamas@gmail.com)

\section{PÁLYÁZATI FELHÍVÁS}

Dr. Fehér Jánosnak, a Semmelweis Egyetem II. sz. Belgyógyászati Klinika volt igazgatójának és az Orvosi Hetilap volt föszerkesztőjének emlékére létrehozott Dr. Fehér János Emlékére Alapítvány minden évben pályázatot ír ki egyetemi hallgatók, fiatal egyetemi oktatók és $\mathrm{PhD}$-hallgatók részére, akik a belgyógyászatban, különösen a hepatológiában végzett kutatási eredményeiket az Orvosi Hetilapban publikálják.

A kéziratot „Dr. Fehér János pályázat” megjelöléssel 2019. április 15-ig kell feltölteni az Orvosi Hetilap Editorial Manager rendszerébe.

A pályázathoz mellékelni kell a pályázó önéletrajzát.

A díj odaítéléséről az Alapítvány kuratóriuma dönt. A díj átadására a Markusovszky Lajos-ünnepségen, 2019. májusában kerül sor, ahol a nyertes pályázó rövid előadásban ismertetheti eredményeit. 